\title{
Photovoltaic Emulator Berbasis Embedded System pada Jaringan Listirk Cerdas
}

\author{
Fitra Purnama Adi ${ }^{1}$, Khairudin ${ }^{2}$, Lukmanul Hakim ${ }^{3}$ \\ Jurusan Teknik Elektro, Fakultas Teknik, Universitas Lampung \\ Jalan Soemantri Brojonegoro No.1, Bandar Lampung, 35141 \\ $1_{\text {fitra.purnama1055estudents.unila.ac.id }}$ \\ 2 khairudindeng.unila.ac.id \\ ${ }^{3}$ plgsekipdeng.unila.ac.id
}

Intisari - Photovoltaic Emulator merupakan alat yang dirancang untuk meniru karakteristik tegangan dan arus keluaran dari pembangkit listrik tenaga surya. Penelitian ini bertujuan untuk merancang dan mengimplementasikan Photovoltaic Emulator dengan menggunakan rangkaian elektronika daya dengan pemrograman pemodelan panel surya. Penyinaran mataharai dan suhu harian digantikan mikrokontroler dengan chip ATMega 328P sebagai komponen pengendali dan pemantau. Berdasarkan hasil pengujian, Photovoltaic Emulator yang dibuat dalam studi ini terbukti dapat meniru karakteristik tegangan dan arus keluaran dari panel surya dengan masukan irradiance dan suhu harian pada suatu daerah.

Pengukuran menggunakan sensor arus dengan rata-rata galat senilai $2.601 \%$ dan sensor tegangan dengan rata-rata galat senilai $1,971 \%$ dibandingkan dengan pengukuran multimeter. Persentase kemiripan karakteristik keluaran Photovoltaic Emulator dengan panel surya yang ditiru yaitu 95.13\%. Setiap data disimpan berdasarkan waktu pada secure digital card melalui datalogger.

Kata kunci - Photovoltaic Emulator, Smart Grid, Embedded System.

Abstract - Photovoltaic Emulator is a device designed for emulating voltage and current output characteristics of a solar panel. The purposes of this research are to design and to develop a Photovoltaic Emulator based on power electronic components and solar panel modeling software. The solar radiation as well as daily temperature were represented by a microcontroller with 328P ATMega chip as a controlling and monitoring component. From experiment results, the emulator is able to mimic voltage and current characteristics of the solar panel based on the irradiance and daily temperature in a certain area.

The error measurement of the voltage and current sensor are $1.971 \%$ and $2.601 \%$ respectively compared to the multimeters. The similarity of Photovoltaic Emulator output characteristics with solar panels is 95.13\%. Each data was stored based on time in the secure digital card through data logger.

Keywords - Photovoltaic Emulator, Smart Grid, Embedded System 


\section{PENDAHULUAN}

Perkembangan teknologi yang diiringi dengan bertambahnya peralatan-peralatan listrik yang dapat mempermudah kehidupan manusia sehari-hari menyebabkan penggunaan energi listrik yang meningkat. Semakin meningkatnya penggunaan energi listrik perlu diimbangi dengan penyediaan energi listrik pada sisi pembangkitan. Penyediaan energi listrik saat ini mulai menggunakan sumber energi listrik terbarukan sebagai salah satu penyelesaian masalah kesetimbangan pada sistem tenaga listrik.

Sistem Smart Grid merupakan salah satu solusi dalam mengatasi masalah kesetimbangan sistem tenaga listrik. Pada sistem Smart Grid, pembangkit energi terbarukan terhubung dengan pembangkit konvensional yang dioperasikan berdasarkan teknologi informasi dan komunikasi secara otomatis sehingga dapat meningkatkan efisiensi, ekonomi dan keberlanjutan pembangkitan serta distribusi listrik. Dalam upaya meningkatkan keandalan dan keamanan sistem diperlukan penelitian pada sistem Smart Grid. Perealisasian dari sistem Smart Grid memerlukan biaya mahal dan waktu yang cukup panjang. Sehingga diperlukan sistem tiruan dari Smart Grid dalam skala yang lebih kecil yang dapat digunakan dalam analisa sistem Smart Grid.

Smart Grid Emulator merupakan sistem tiruan dari sistem Smart Grid yang terdiri dari pembangkit-pembangkit, transmisi dan berbagai variasi karakteristik beban yang dapat merepresentasikan pada keadaan sebenarnya. Pada sisi pembangkit terdapat pembangkit listrik yang menggunakan energi terbarukan yang terhubung dengan pembangkit listrik konvensional sehingga dapat mempermudah dalam penganalisaan daya yang dibangkitkan pada sistem tenaga listrik.

Pembangkit listrik tenaga surya merupakan salah satu dari pembangkit listrik energi terbarukan. Pada tugas akhir ini, penulis membahas mengenai sistem Smart Grid emulator yang berfokus pada sisi pembangkit yaitu Photovoltaic Emulator berbasis embedded system. Pembangkit listrik yang dipengaruhi oleh radiasi matahari dan suhu harian akan digantikan menggunakan mikrokontroler dengan chip ATMega 328P sebagai komponen pengendali. Sehinnga daya keluaran dari Photovoltaic Emulator akan sama dengan daya yang dikeluarkan oleh pembangkit listrik tenaga surya pada keadaan sebenarnya dalam skala yang diperkecil.

\section{TINJAUAN PUSTAKA}

\section{A. Smart Grid}

Smart Grid merupakan jaringan listrik cerdas yang menggunakan teknologi informasi dan komunikasi untuk pengoperasiannya dan bertindak berdasarkan informasi, seperti sebuah informasi mengenai reaksi atau tindakan dari penyedia dan konsumen, digunakan secara otomatis untuk meningkatkan efisiensi, keandalan, ekonomi dan keberlanjutan pembangkit serta distribusi listrik. Di sisi lain untuk mengevaluasi dan memvalidasi gagasan baru mengenai Smart Grid dilingkungan laboratorium memerlukan platform eksperimental yang bagus, baik berupa simulator perangkat lunak dan emulator, sehingga tidak mengganggu beroperasinya sistem Smart Grid pada sistem tenaga listrik yang tersedia [1].

Berdasarkan standar internasional IEC 61850 dan 61968, mendefinisikan keseluruhan arsitektur Smart Grid dan karakteristiknya dapat diringkas sebagai berikut [2]:

- Self-Healing dengan cara mendeteksi dan respon langsung terhadap masalah sistem serta melakukan pemulihan.

- Penyediaan kualitas daya yang tinggi kepada seluruh konsumen dan pelanggan industri.

- Mengakomodasi berbagai pilihan pembangkitan dalam skala regional.

- Pemberdayaan pelanggan dengan memperbolehkan melakukan manajemen energi.

- Toleransi serangan dengan kemapuan dapat tahan terhadap serangan fisik dan cyber.

Teknologi smart grid dapat digunakan menjadi solusi produktivitas penyediaan tenaga listrik dari energi terbarukan karena dapat menyediakan pembangkit listrik dari local 
energy resource, pengembangan sistem dan integrasi pembangkit listrik serta interkoneksi antar sistem terisolasi dan hybrid dapat dilakukan, sehingga pemanfaatan energi terbarukan menjadi optimal dan efisien [3].

\section{1) Smart Grid Emulator}

Smart Grid Emulator merupakan suatu tiruan atau prototipe dari sistem Smart Grid yang berguna untuk analisa dari keadaan nyata berupa simulasi maupun emulasi. Dalam penerapan Sistem Smart Grid perlu dipertimbangkan untuk kelayakan dan kemungkinan sistem dapat bekerja dengan baik, sehingga perlu dilakukan penelitian terlebih dahulu. Smart grid emulator juga dapat secara langsung digunakan untuk pembelajaran mengenai sistem smart grid.

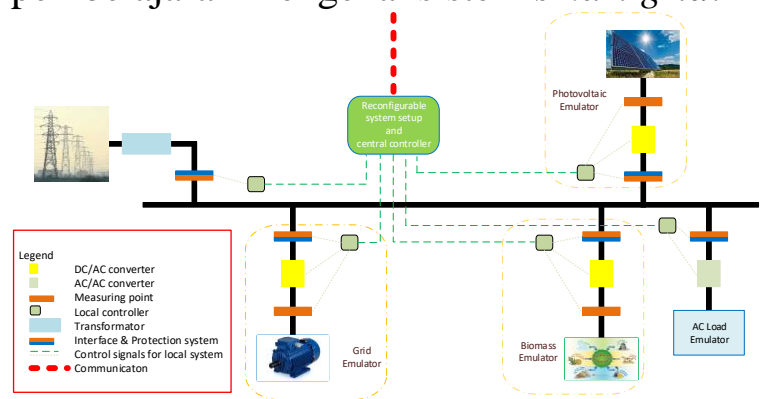

Gbr. 1. Smart Grid Emulator

\section{B. Photovoltaic Emulator}

Photovoltaic Emulator merupakan pembangkit listrik tenaga surya tiruan yang dibuat untuk meniru karakteristik arus dan tegangan keluaran yang ada solar panel. Pada photovoltaic emulator dimana kondisi lingkungan dapat terkendali, tidak terpengaruh oleh faktor eksternal seperti suhu dan cuaca. Hal ini memungkinkan emulator photovoltaic dapat digunakan secara berulang untuk menguji peralatan-peralatan [4].

\section{Karakteristik Sel Surya}

1) Rangkaian Ekivalen Sel surya

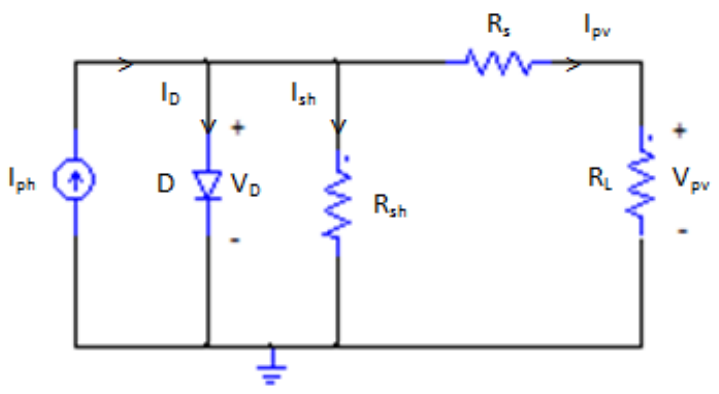

Gbr. 2. Rangkaian ekivalen photovoltaic
Berdasarkan rangkain diatas photocurrent $\left(\mathrm{I}_{\mathrm{ph}}\right)$ adalah arus yang dihasilkan langsung akibat penyinaran matahari pada sel surya. Arus ini bervariasi berdasarkan radiasi matahari yang terpapar ke sel surya dan suhu pada sel surya tersebut. Hambatan $\mathbf{R}_{\mathrm{s}}$ dan $\mathbf{R}_{\mathrm{sh}}$ menunjukkan hambatan intrinsik seri dan paralel dari sel. Besarnya arus sel surya adalah arus photocurrent dikurangi dengan arus dioda dan arus pada hambatan paralel, yang dirumuskan sebagai berikut,

$I_{p D}=I_{p h}-I_{D}-I_{r s h}$

Dapat dijabarkan dengan persamaan berikut [5],

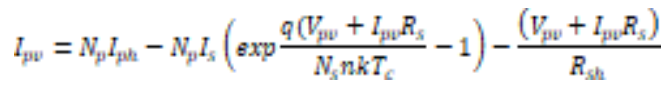

Dimana,

$\mathrm{I}_{\mathrm{pv}} \quad=$ Arus Photovoltaic

$\mathrm{I}_{\mathrm{ph}} \quad=$ Photocurrent

$\mathrm{I}_{\mathrm{D}} \quad=$ Arus pada dioda

$\mathrm{I}_{\mathrm{rsh}} \quad=$ Arus hambatan shunt

$\mathrm{I}_{\mathrm{S}} \quad=$ Arus saturasi sel surya

$\mathrm{q} \quad=$ Elektron $=1.6 \times 10^{-19} \mathrm{C}$

$\mathrm{V}_{\mathrm{pv}} \quad=$ Tegangan pada sel

$\mathrm{T}_{\mathrm{c}} \quad=$ Suhu kerja sel

$\mathrm{R}_{\mathrm{s}} \quad=$ Hambatan seri

$\mathrm{R}_{\mathrm{sh}} \quad=$ Hambatan shunt

$\mathrm{n} \quad=$ Faktor ideal

$\mathrm{k}=$ Konstanta Boltzmann $\left(1.38 \times 10^{-23} \mathrm{~J} / \mathrm{K}\right)$

$\mathrm{N}_{\mathrm{s}} \quad$ = Jumlah sel surya yang disusun seri

$\mathrm{N}_{\mathrm{p}} \quad$ = Jumlah sel surya yang disusun paralel

- Arus photovoltaic

$I_{p h}=\left[I_{s e}+K_{i}\left(T_{c}-T_{\text {ref }}\right)\right] \frac{\beta}{\beta_{\text {ref }}}$

Dimana,

$\mathrm{B}=$ Solar irradiance

$\mathrm{B}_{\mathrm{ref}}=$ Solar irradiance reference $\left(1000 \mathrm{~W} / \mathrm{m}^{2}\right)$

$\mathrm{K}_{\mathrm{i}} \quad=$ Koefisien suhu dari arus $\mathrm{I}_{\mathrm{sc}}$

$\mathrm{I}_{\mathrm{sc}}=$ Arus hubung singkat pada suhu kerja

$\mathrm{T}_{\text {ref }}=$ Suhu reference $\left(25^{\circ} \mathrm{C}=298^{\circ} \mathrm{K}\right)$

$\mathrm{I}_{\mathrm{rs}} \quad=$ Arus saturasi gelap [6]. 
- Arus saturasi sel surya

$I_{s}=I_{r s}\left[\frac{T_{c}}{T_{r e f}}\right]^{3} \exp \left[\frac{q E_{q q}}{n k}\left\{\frac{1}{T_{r e f}}-\frac{1}{T_{c}}\right\}\right]$

- Arus saturasi gelap,

$I_{r s}=I_{g e-r e f} /\left[\exp \left(q V_{\text {oe-ref }} / N_{\mathrm{g}} k n T_{\text {ref }}\right)-1\right]$

Dimana,

$\mathrm{I}_{\mathrm{sc}-\mathrm{ref}}=$ Arus hubung singkat pada standar test condition

$\mathrm{V}_{\text {oc-ref }}=$ Tegangan hubung singkat pada standar test Conditions.

- Hambatan seri

$R_{s}=\frac{\frac{N_{g} n k T_{c}}{q} l_{n}\left(1-\frac{I_{m}}{I_{s e}}\right)+V_{o c}-V_{m}}{I_{m}}$

- Faktor Ideal

$n=\frac{q\left(2 V_{m}-V_{o c}\right)}{N_{g} k T\left(\frac{I_{s c}}{I_{s c}-I_{m}} l_{n}\left(1-\frac{I_{m}}{I_{s c}}\right)\right)}$

Dimana,

$\mathrm{I}_{\mathrm{m}} \quad=$ Arus maksimum sel surya

$\mathrm{V}_{\mathrm{m}} \quad=$ Tegangan maksimum sel surya

- Hambatan Paralel

$R_{s h}=\frac{0,5 V_{o c}-V_{s e}}{I_{s e r}-I_{x}}$

Dimana,

$\mathrm{V}_{\mathrm{oc}}=$ Tegangan open circuit sel surya

$\mathrm{V}_{\mathrm{sc}}=$ Tegangan short circuit sel surya

$\mathrm{I}_{\mathrm{sc}}=$ Arus hubung singkat pada suhu kerja [7].

2) Kurva Karakteristik Sel Surya

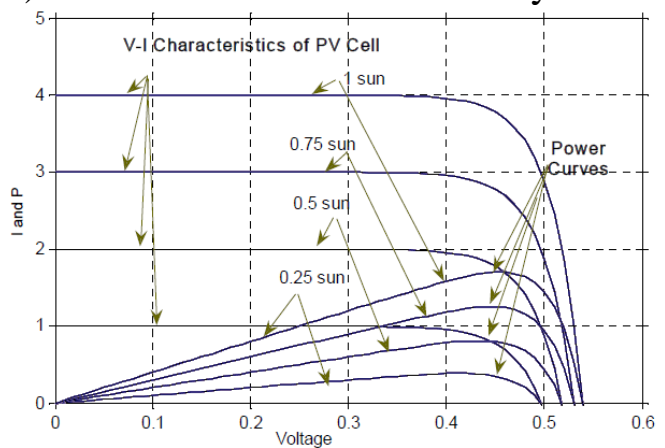

Gbr. 3. Kurva karakteristik terhadap perubahan irradiance matahari

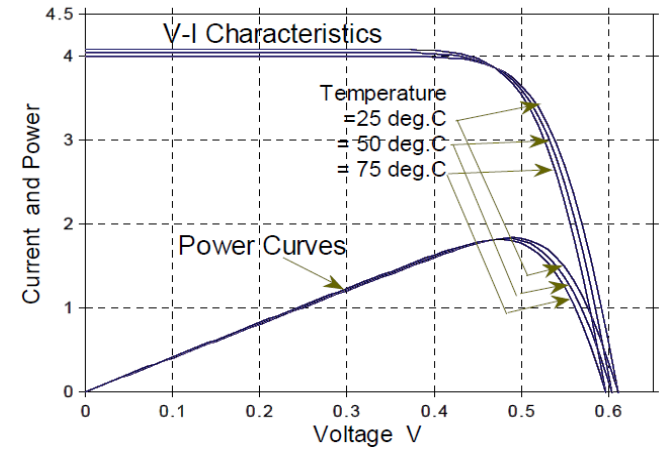

Gbr. 4. Kurva karakteristik terhadap perubahan suhu [8].

\section{Buck-Boost Converter}

Pada dasarnya, buck-bosst converter yang merupakan salah satu jenis dari topologi dari switching power supply terdiri dari 2 bagian, yaitu bagian power dan bagian kontrol. Bagian power berfungsi untuk konversi tegangan dengan menggunakan komponen switch dan filter output.

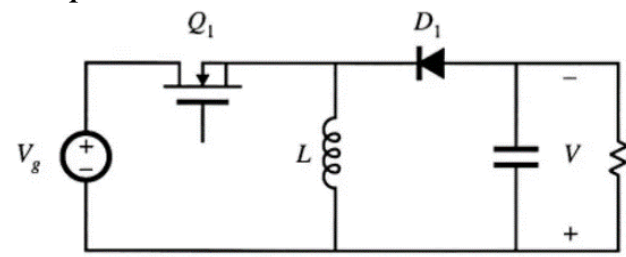

Gbr. 5. Topologi Buck-Boost Converter

1) Penentuan Filter LC

$V_{o}=-V_{s}\left(\frac{D}{1-D}\right)$

Dalam menentukan besarnya nilai inductor, diperlukan nilai resistansi pada rangkaian buck-boost converter menggunakan persamaan berikut,

$R=\frac{V_{o}}{I_{\mathrm{o}}}$

Dimana,

$\mathrm{R} \quad=$ Resistansi

$\mathrm{I}_{\mathrm{O}} \quad=$ Arus Keluaran

$\mathrm{V}_{\mathrm{o}} \quad=$ Tegangan Keluaran

Sehingga nilai minimal induktor yaitu:

$L_{\min }=\frac{(1-D)^{2} R}{2 f}$ 
Dimana,

$\mathrm{L}_{\min }=$ Nilai Minimal Induktor (induktansi)

$\mathrm{D} \quad=$ Duty cycle

$\mathrm{R} \quad=$ Resistansi

$\mathrm{F} \quad=$ Frekuensi.

Sedangkan besar nilai kapasitor pada rangkaian buck-boost converter dapat diketahui dengan persamaan berikut [9].

$C=\frac{V_{o} D}{\Delta V_{r} R f}$

Dimana,

$\mathrm{C}=$ Nilai Kapasitor

$V_{\circ} \quad=$ Tegangan Keluaran

$\Delta V_{\odot} \quad=$ Tegangan Keluaran Ripple.

E. Pengendalian dan Pemantauan Photovoltaic Emulator

Pengendalian dan pemantauan pada Photovoltaic Emulator menggunakan mikrokontroler Arduino Uno berfungsi sebagai pengontrol rangkaian elektronik. Pada Arduino Uno terdapat chip ATMega 328P. Arduino Uno memiliki beberapa jumlah pin yang terdiri atas 6 input analog, 14 pin digital, dan 6 pin output (PWM). Selain itu Arduino Uno memiliki osilator kristal $16 \mathrm{MHz}$, kabel USB dan power jack,

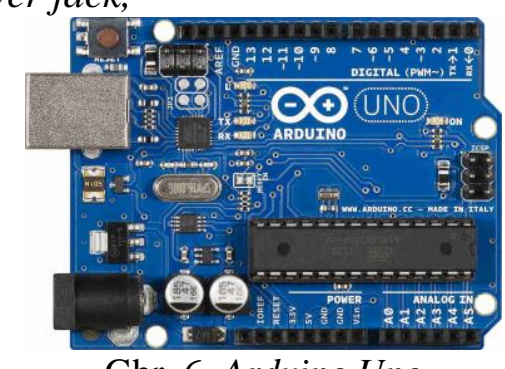

Gbr. 6. Arduino Uno

\section{METODOLOGI PENELITIAN}

\section{A. Tahapan Penelitian}

Beberapa tahapan pada penelitian ini adalah sebagai berikut:

1. Studi Literatur

2. Konsep Perancangan Sistem

3. Perancangan Sistem

4. Pengujian Sistem

5. Pengambila Data

6. Analisis Data.

\section{B. Spesifikasi Komponen}

Adapun alat dan bahan yang digunakan pada penelitian ini yaitu:

1. Arduino Uno sebagai mikrokontroler.

2. Perangkat lunak Arduino 1.6.12 sebagai program untuk source code LIFA.

3. Perangkat lunak Matlab 2015a sebagai aplikasi untuk mensimulasikan rancangan PV.

4. Power Supply sebagai sumber tegangan.

5. DC-DC Converter (Buck-Boost)

6. Gate driver sebagai penguat sinyal PWM dari mikrokontroler.

7. Sensor arus ACS712 sebagai pembaca nilai arus keluaran.

8. Sensor tegangan ZMPT101B sebagai pembaca nilai tegangan keluaran.

9. Kartu Memori sebagai penyimpan data hasil pengukuran sensor.

10. Kendali Proporsional Integral Derivatif (PID) digunakan untuk mencapai setpoint pada pemodelan photovoltaic.

\section{Perencanaan Modul Sistem}

Perancangan model sistem dilakukan dengan pembuatan perangkat sistem. Perangkat sistem terdiri dari mikrokontroler Arduino Uno, buck-boost converter, gate driver, power supply, sensor arus dan sensor tegangan.

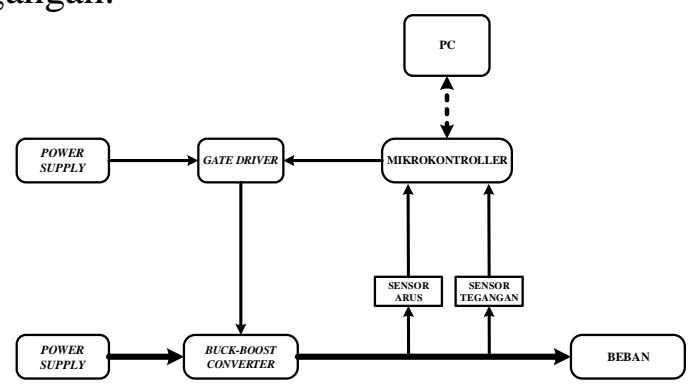

Gbr. 7. Blok diagram perancangan alat

\section{HASIL DAN PEMBAHASAN}

\section{A. Realisasi Photovoltaic Emulator}

Rancang bangun Photovoltaic Emulator yang terdiri dari beberapa komponen yaitu Arduino Uno sebagai mikrokontroler yang berfungsi untuk mengkoordinasiakan komponen-komponen yang lain berupa sensor, buck-boost converter dan data logger. Sensor yang digunakan pada Photovoltaic Emulator yaitu sensor tegangan dan sensor arus yang 
diletakkan pada sisi output. Sensor tegangan berfungsi untuk mendeteksi besar nilai tegangan yang keluar dan sensor arus. Buckboost converter pada Photovoltaic Emulator berfungsi untuk menaikkan dan menurunkan tegangan keluaran untuk mencapai setpoint. Gate driver berfungsi untuk menaikkan tegangan PWM dari mikrokontroler sebesar 5 $\mathrm{V}$ menjadi $15 \mathrm{~V}$. Catu daya berfungsi sebagai sumber masukan untuk buck-boost converter dan gate driver.

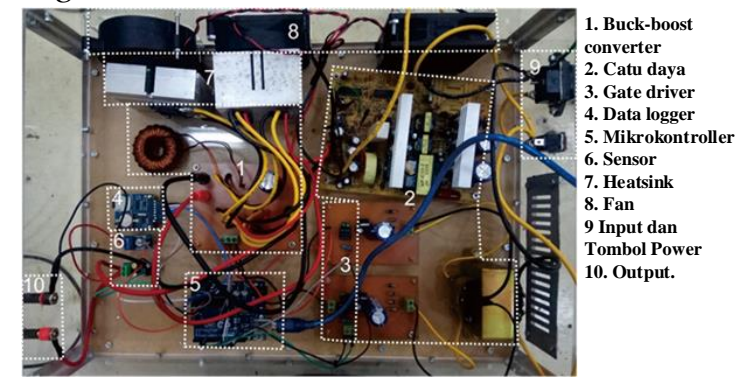

Gbr. 8. Rancang bangun photovoltaic emulator.

\section{B. Hasil Data Photovoltaic Emulator}

1) Irradiance Bervariasi dan Suhu Tetap

Peniruan karakteristik panel surya dilakukan dengan keadaan irradiance yang berbeda-beda yaitu saat irradiance sebasar $1000 \mathrm{~W} / \mathrm{m}^{2}, 800 \mathrm{~W} / \mathrm{m}^{2}, 600 \mathrm{~W} / \mathrm{m}^{2}, 400 \mathrm{~W} / \mathrm{m}^{2}$ dan $200 \mathrm{~W} / \mathrm{m}^{2}$ dengan nilai temperatur yang tetap sesuai dengan nilai temperature refrensi untuk panel surya yaitu $25^{\circ} \mathrm{C}$,

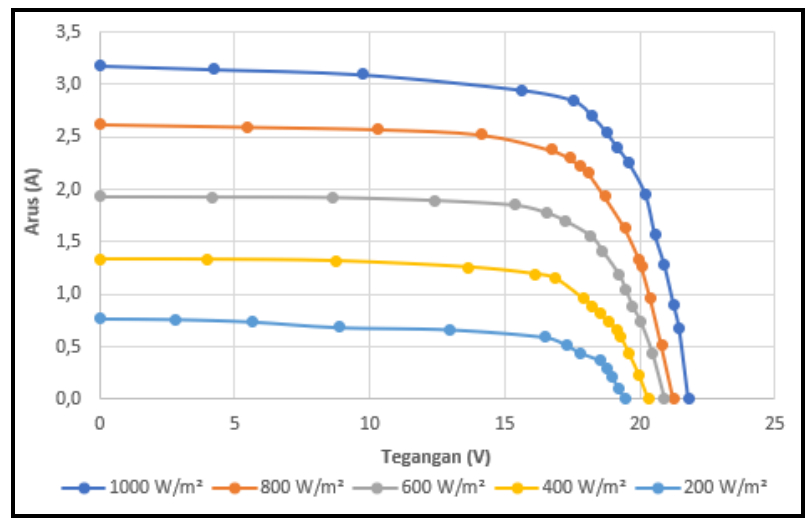

Gbr. 9. Karakteristik keluaran photovoltaic emulator dengan irradiance yang bervariasi.

\section{2) Suhu Bervariasi dan Irradiance Tetap}

Peniruan karakteristik panel surya dilakukan dengan keadaan temperature yang berbeda-beda yaitu saat irradiance sebasar $0^{\circ}$ $\mathrm{C}, 25^{\circ} \mathrm{C}, 50^{\circ} \mathrm{C}$ dan $75^{\circ} \mathrm{C}$ dengan nilai irradiance yang tetap sesuai dengan nilai irradiance refrensi untuk panel surya yaitu $1000 \mathrm{~W} / \mathrm{m}^{2}$.

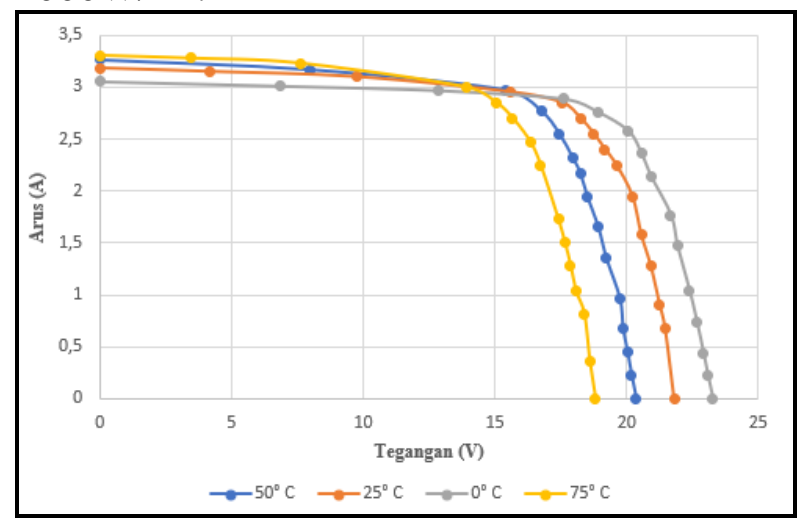

Gbr. 10. Karakteristik keluaran photovoltaic emulator dengan suhu bervariasi.

Pada saat temperatur $0^{\circ} \mathrm{C}$ di dapatkan keluaran daya maksimum yaitu $52.236 \mathrm{~W}$, temperatur $25^{\circ} \mathrm{C}$ didapatkan keluaran daya maksimum yaitu $49.961 \mathrm{~W}$, saat temperatur $50^{\circ} \mathrm{C}$ didapatkan keluaran daya maksimum yaitu $46.470 \mathrm{~W}$ dan padasaat temperatur $75^{\circ} \mathrm{C}$ didapatkan keluaran daya maksimum yaitu $42.883 \mathrm{~W}$ Berdasarkan gambar 4.7 dapat dilihat bahwa nilai temperatur yang berubahubah mempengaruhi besar nilai keluaran arus sehingga semakin besar nilai irradiance maka semakin besar daya keluaran dan karakteristik keluaran tegangan dan arus dari Photovoltaic Emulator.

3) Perbandingan Karakteristik Keluaran Photovoltaic Emulator Terhadap Panel Surya yang Ditiru

Pada penelitian ini menggunakan panel surya Solar Electric Supply dengan tipe 450J dengan daya keluran maksimum 50 Watt. Pada standard test condition tegangan keluaran maksimum panel surya yaitu $17.5 \mathrm{~V}$ dan arus keluaran maksimum yaitu 2.9 A. Sedangkan pada kondisi open circuit tegangan keluaran panel surya yaitu $21.8 \mathrm{~V}$ dan arus yaitu $0 \mathrm{~A}$. Dan pada kondisi short circuit tegangan keluaran panel surya yaitu $0 \mathrm{~V}$ dan arus keluaran 3.2 A. Berikut merupakan grafik perbandingan karakteristik tegangan dan arus keluaran dari Photovoltaic Emulator dengan panel surya surya Solar Electric Supply dengan tipe 450J. 


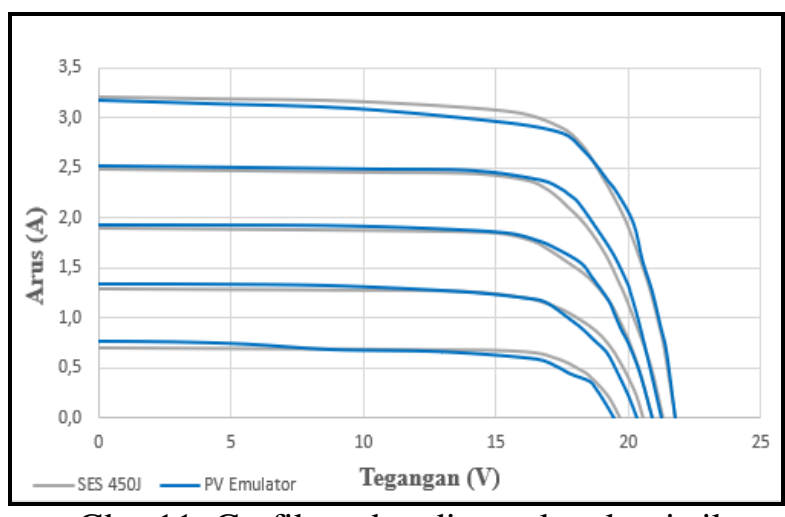

Gbr. 11. Grafik perbandingan karakteristik keluaran Photovoltaic Emulator dengan panel surya SES 450J.

Pada Gambar 11 merupakan grafik perbandingan karakteristik tegangan dan arus keluaran dari Photovoltaic Emulator dengan panel surya Solar Electric Supply dengan tipe 450J, dimana terdapat nilai galat rata-rata yaitu $4.87 \%$, sehingga persentase kemiripan antara Photovoltaic Emulator dengan panel surya Solar Electric Supply dengan tipe 450J yaitu $95.13 \%$.

\section{Analisis dan Pembahasan}

1) Pola Irradiance dan Suhu

Pola irradiance dan suhu yang digunakan sebagai input bagi Photovoltaic Emulator sehingga dapat merefresentasikan panel surya yang terpapar sinar matahari pada suatu tempat dan waktu tertentu. Adapun data irradiance dan suhu yang digunakan yaitu dari penelitian terdahalu. Berikut merupakan grafik nilai irradiasi dan suhu,

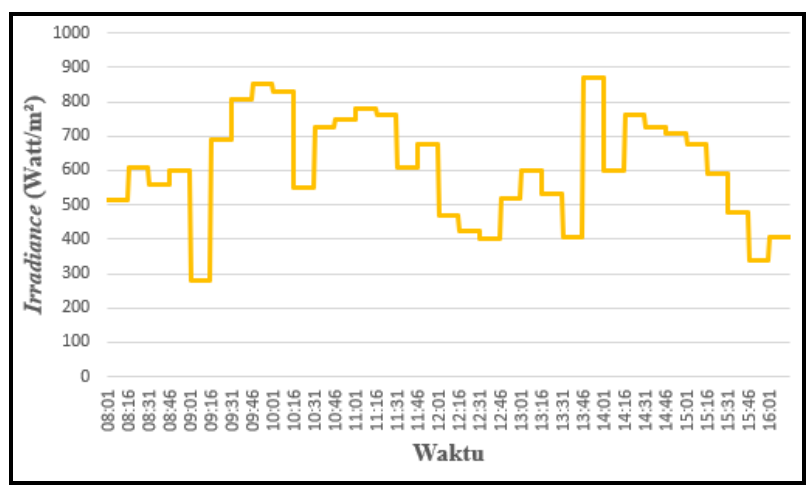

Gbr. 12. Grafik data irradiance harian panel surya

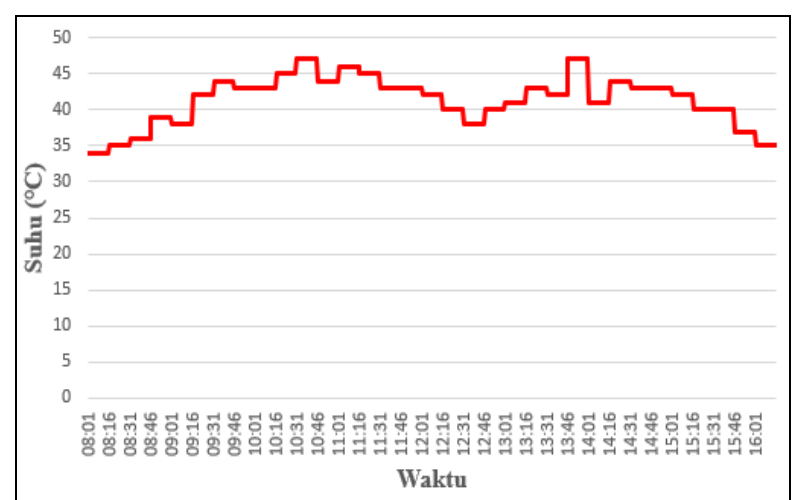

Gbr. 13. Grafik data suhu harian panel surya

Nilai irradiance dan suhu selalu berubahubah menyesuaikan kondisi di lapangan. Nilai irradiance tertingi yang terukur yaitu 870 Watt $/ \mathrm{m}^{2}$ pada pukul 13.46 sampai $14.00 \mathrm{WIB}$ dan suhu tertinggi yang terukur yaitu $47^{\circ} \mathrm{C}$ pada pukul 10.31 sampai 10.45 dan 13.46 sampai 14.00 WIB [10].

2) Keluaran Photovoltaic Emulator

Berikut merupakan grafik hasil tiruan Photovoltaic Emulator pada percobaan menggunakan data irradiance dan suhu harian.

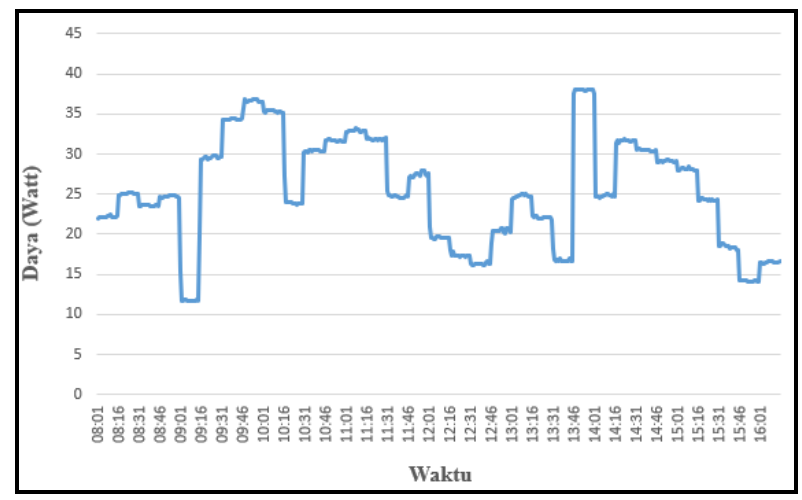

Gbr. 14. Daya keluaran photovoltaic emulator.

Berdasarkan gambar 14 merupakan grafik daya keluaran Photovoltaic Emulator dengan menggunakan masukan irradiance dan suhu harian dengan nilai yang berbeda pada setiap 15 menit. Nilai daya keluaran tertinggi yaitu 37.94 Watt pada pukul 13.46 sampai 14.00 dengan nilai irradiance sebesar $870 \mathrm{Watt} / \mathrm{m}^{2}$ dan suhu $47^{\circ}$ C. Sedangkan daya keluaran terendah yaitu 11.71 Watt yaitu pada pukul 09.01 sampai 09.15 dengan nilai irradiance sebesar $280 \mathrm{Watt} / \mathrm{m}^{2}$ dan suhu $38^{\circ} \mathrm{C}$. 


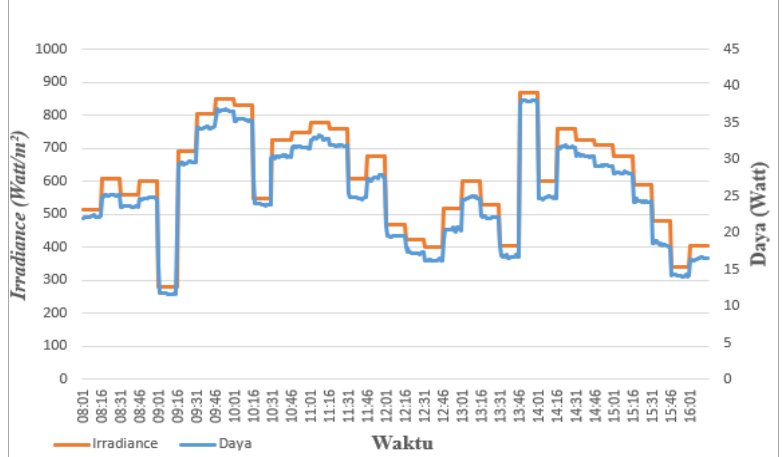

Gbr. 15. Perbandingan daya keluaran dengan nilai irradiance.

$\begin{array}{cccr}\text { Gambar } & 15 & \text { merupakan } & \text { grafik } \\ \text { perbandingan } & \text { daya } & \text { keluaran } & \text { dengan }\end{array}$ irradiance. Pada saat irradiance bernilai 690 Watt $/ \mathrm{m}^{2}$, daya keluaran yaitu $29.53 \mathrm{Watt}$. Pada saat irradiance bernilai $805 \mathrm{Watt} / \mathrm{m}^{2}$, daya keluaran yaitu 34.33 Watt. Dan pada saat irradiance bernilai $850 \mathrm{Watt} / \mathrm{m}^{2}$, daya keluaran yaitu 36.62 Watt. Semakin besar nilai irradiance maka akan semakin besar daya keluaran dari Photovoltaic Emulator, sehingga irradiance dengan daya keluaran berbanding lurus dan tidak linier.

\section{KESIMPULAN}

Photovoltaic Emulator yang dirancang dan dibangun dapat meniru karakteristik tegangan dan arus keluaran dari panel surya. Keluaran dari Photovoltaic Emulator diatur secara otomatis dengan menggunakan embedded system berdasarkan perubahan nilai irradiance dan suhu pada suatu daerah. Hasil pengukuran sensor arus dan sensor tegangan dibandingkan dengan multimeter, didapatkan nilai galat yang menyatakan sensor tegangan dan sensor arus termasuk alat ukur kerja. Persentase kemiripan karakteristik keluaran Photovoltaic Emulator dengan panel surya SES 450J yaitu $95.13 \%$.

\section{REFERENSI}

[1] S. Tan, "SCORE : Smart-Grid Common Open Research Emulator," IEEE SmartGridComm 2012 Symposium Performance Analysis and Simulation, pp. 282-287, 2012.
[2] Momoh, J.A.; "Smart grid design for efficient and flexible power networks operation and control", In Proc. IEEE Power Systems Conference and Exposition, pp 1-8, 2009.

[3] T. S. G. d. D. E. PT PLN, "PLN' s Smart Grid Planning \& Implementation : Challenges \& Opportunities," in 2nd PJCI National Conference, Jakarta, 2017.

[4] Dale Dolan, "Simulation of A Photovoltaic Emulator," IEEE, pp. 1-6, 2010.

[5] W. De Soto, "Improvement and Validation of a Model for Photovoltaic Array Performance," ELSEVIER, pp.1-11, 2006.

[6] N. Pandiarajan, "Mathematical Modeling of Photovoltaic Module With Simulink," ICESS (International Conference on Electrical Energy System), pp. 314-319, 2011.

[7] R. Khezzar, "Comparative Study of Mathematical Methods for Parameters Calculation of Current-Voltage Characteristic of Photovoltaic Module," Universite Mentouri, Algeria. Pp. 24-28, 2009.

[8] M. Petkov, "Modelling of Electrical Characteristics of Photovoltaic Power Supply Sources," Brief Scientific Paper. Contemporary Materials (Renewable Energy Source), II-2. Pp 171-177, 2011.

[9] Daniel W. Hart, "Power Elektronics", University Valparaiso, Mc. Graw-Hill International Edition, 2011.

[10]D.S. Agung, "Rancang Bangun Alat Kontrol Panel Surya Dengan Teknik Maximum Power Point Tracker (MPPT) Menggunakan Algoritma Hill Climbing," Universitas Lampung, 2018. 